\title{
Structure-Function and Industrial Relevance of Bacterial Aminopeptidase $\mathbf{P}$
}

\author{
Muhamad Nadzmi Omar 1,2, Raja Noor Zaliha Raja Abd Rahman 1,3®D, Noor Dina Muhd Noor 1,2®D, \\ Wahhida Latip ${ }^{1,3} \mathbb{D}_{\text {, Victor Feizal Knight }}{ }^{4}$ and Mohd Shukuri Mohamad Ali 1,2,* \\ 1 Enzyme and Microbial Technology Research Centre, Faculty of Biotechnology and Biomolecular Sciences, \\ Universiti Putra Malaysia, Serdang 43400, Malaysia; nadzmiomar@gmail.com (M.N.O.); \\ rnzaliha@upm.edu.my (R.N.Z.R.A.R.); dina@upm.edu.my (N.D.M.N.); wahhidalatip@gmail.com (W.L.) \\ 2 Department of Biochemistry, Faculty of Biotechnology and Biomolecular Sciences, Universiti Putra Malaysia, \\ Serdang 43400, Malaysia \\ 3 Department of Microbiology, Faculty of Biotechnology and Biomolecular Sciences, Universiti Putra Malaysia, \\ Serdang 43400, Malaysia \\ 4 Research Center for Chemical Defence, National Defence University of Malaysia, Kem Perdana Sungai Besi, \\ Kuala Lumpur 57000, Malaysia; victor.feizal@upnm.edu.my \\ * Correspondence: mshukuri@upm.edu.my; Tel.: +60-3-9769-6721
}

Citation: Omar, M.N.; Raja Abd Rahman, R.N.Z.; Muhd Noor, N.D.; Latip, W.; Knight, V.F.; Ali, M.S.M. Structure-Function and Industrial Relevance of Bacterial

Aminopeptidase P. Catalysts 2021, 11, 1157. https://doi.org/10.3390/ catal11101157

Academic Editor: Richard C. Holz

Received: 3 September 2021

Accepted: 22 September 2021

Published: 26 September 2021

Publisher's Note: MDPI stays neutral with regard to jurisdictional claims in published maps and institutional affiliations.

Copyright: (c) 2021 by the authors. Licensee MDPI, Basel, Switzerland. This article is an open access article distributed under the terms and conditions of the Creative Commons Attribution (CC BY) license (https:/ / creativecommons.org/licenses/by/ $4.0 /)$.
Abstract: Aminopeptidase P (APPro, E.C 3.4.11.9) cleaves N-terminal amino acids from peptides and proteins where the penultimate residue is proline. This metal-ion-dependent enzyme shares a similar fold, catalytic mechanism, and substrate specificity with methionine aminopeptidase and prolidase. It adopts a canonical pita bread fold that serves as a structural basis for the metal-dependent catalysis and assembles as a tetramer in crystals. Similar to other metalloaminopeptidase, APPro requires metal ions for its maximal enzymatic activity, with manganese being the most preferred cation. Microbial aminopeptidase possesses unique characteristics compared with aminopeptidase from other sources, making it a great industrial enzyme for various applications. This review provides a summary of recent progress in the study of the structure and function of aminopeptidase $P$ and describes its various applications in different industries as well as its significance in the environment.

Keywords: bacterial aminopeptidase P; structure; manganese; industrial applications; environment

\section{Introduction}

Enzymes from bacteria and other microorganisms have received a lot of interest resulting from their widespread use in various industrial sectors because of their stability, catalytic activity, ease of production, and optimization compared with other plant and animal enzymes [1]. Enzymes that catalyze the hydrolysis of peptide bonds and the breakdown of proteins into smaller amino acids and peptides are referred to as proteases or peptidases. Peptide bonds present between the amino acids of proteins are cleaved by specific proteases [2]. A number of classification systems have been utilized to characterize the aminopeptidases. Generally, the parameters of classification used include substrate specificity, cellular location, catalytic function, required cofactors, and optimum $\mathrm{pH}[3,4]$. Aminopeptidases can be categorized on the basis of their substrate specificity (broad or narrow), catalytic mechanism (serine, metallo, cysteine peptidases), cellular location (cytosolic, membrane, and microsomal), and molecular structure [5-9]. Examples of these enzymes are methionine aminopeptidase, arginine aminopeptidase, leucine aminopeptidase, aminopeptidase A, and aminopeptidase P [10-14].

A proline-specific aminopeptidase, aminopeptidase P (APPro, or Xaa-Pro aminopeptidase; E.C 3.4.11.9, MEROPS M24.004) is a metalloprotease that cleaves N-terminal amino acid residue from polypeptide chains where the second residue is proline [12,15-19]. The unique and special structure of proline stimulates conformational constraints on the peptide bond, shielding it from the common degradation process [20]. The existence of a 
small number of special proteases capable of hydrolyzing the bond between proline and other amino acids, in addition to the tissue distribution and localization of these proteases, suggests that proline plays a role in the regulation of key biological activities [21,22]. These enzymes belong to the M24B family and have a conserved dinuclear active site that is essential for their maximal catalytic activity [23].

In contrast to other metalloaminopeptidases, APPro is a cytoplasmic aminopeptidase and recognizes a restricted scissile Xaa-Pro bond of the polypeptide or protein substrates that may be related to virulence-related phenotypes or other biological activities beyond the ability to degrade proteins in general [24]. This enzyme is encoded by pepP genes that are one of the critical virulence-associated genes identified through a Pseudomonas aeruginosa-Caernohaditis elegans infection model [25]. APPro has been found and characterized from diverse sources, including bacteria, fungi, plants, and from the tissues of several mammalian species. This enzyme is thought to have a role in a number of important biological processes; for example, hormone regulation in mammals and terminal degradation of proline-containing peptides and proteins or organophosphate compounds in bacteria [26]. It has also been shown that APPro from a number of lactococcal strains may contribute to the elimination of bitterness arising from cheese ripening through its participation in peptide degradation following release into the cheese matrix [27]. Besides that, the gene encoding APPro of Escherichia coli has even been recognized as a factor involved in membrane vesicle (OMV) production $[28,29]$.

Since an enzyme with the specificity of APPro was first purified from Escherichia coli (EcAPPro), this enzyme has also been extensively studied in other sources of bacteria. Structural and biochemical studies investigating APPro revealed the presence of a conserved binding pocket for N-terminal substrates [15,30-34]. In this review, the 3D structural features as well as the catalytic mechanisms of bacterial aminopeptidase $\mathrm{P}$ are discussed. The biotechnological applications and industrial relevance of this enzyme are also described.

\section{Structure and Function}

\subsection{Bacterial Aminopeptidase P 3D Structure}

Based on the MEROPS database, metalloproteases of the M24 family require metallic ions such $\mathrm{Mg}^{2+}, \mathrm{Zn}^{2+}, \mathrm{Mn}^{2+}, \mathrm{Ca}^{2+}, \mathrm{Ni}^{2+}, \mathrm{Co}^{2+}$, and $\mathrm{Cu}^{2+}$ as cofactors for methionylaminopeptidase, prolidases, and aminopeptidase P [17,20,23,35]. Amino acid sequence alignments between these enzymes have clearly indicated that catalytic domains display similar 'pita-bread' folds. This pita-bread fold is regularly found in N-terminal imido-, amido-, and amidino-scissile bond cleaving enzymes, and acts as a structural foundation for the metal-dependent catalysis. Typically, this fold is defined as two halves with internal pseudo-twofold symmetry. Each half is made up of an antiparallel beta sheet with two alpha helices on one side and the active site on the other, which is surrounded by loops from both halves. A cavity is created in the middle of both halves, between the two antiparallel-sheets (by the loops), where the metallic cofactor binding site is located. The C-terminal region is located on the opposite side of the catalytic cavity in the center of the alpha helices and half domains [36].

The M24 family consists of two subfamilies; i.e., subfamily A includes methionyl aminopeptidase, which is involved in removing the initiator methionine from cytoplasmic proteins (E.C 3.4.11.8), and subfamily B includes the prolidase (Xaa-Pro dipeptidase, E.C 3.4.13.9) and aminopeptidase P (Xaa-Pro aminopeptidase, E.C 3.4.11.9) [37-40]. Homodimeric (with examples found in bacteria, eukaryotes, and Archaea), homotetramers (two dimers linked in any bacteria), and homohexamers (three dimers associated in certain bacterial examples such as those from the Firmicutes phylum) are the functional and biological structures of the M24B subfamily [24,36,41]. In fact, their quaternary structure is obtained through the formation of hydrogen and salt bridges between the monomers, and these interactions have been postulated to be essential for their biological functions $[42,43]$. The activity of these bacterial aminopeptidases is localized in the cytoplasm, on membranes 
associated with the cell envelope, or secreted into the extracellular media. Generally, the Escherichia coli expression system is used for the production of recombinant proteins in order to study their structure and functions.

APPro encoded by PepP gene has been found and characterized from diverse sources such as Escherichia coli [17,44] Neisseria gonorrhoeae [45], Thermococcus sp. strain NA1 [46], Lactococcus lactis ssp. lactis NCDO 763 [47], Lactococcus lactis ssp. cremoris AM2 [27], Pseudomonas aeruginosa [18], human cytosolic [48], Caenorhabditis elegans [49], Plasmodium falciparum [42], fungi, plants, and tissues from several mammalian species [41]. APPro also has been found in nematodes and protozoans $[42,43,49]$. Currently, the three-dimensional structures of bacterial APPros from E. coli [15], Pseudomonas aeruginosa [18], and Deinococcus radiodurans [50] have been determined by X-ray crystallography, as shown in Table 1. In this review, the crystal structures of bacterial APPros from Escherichia coli and Pseudomonas aeruginosa are used as examples in this section to demonstrate the similarities and differences in their 3D structure.

Table 1. Comparison data of bacterial APPro crystal structures.

\begin{tabular}{|c|c|c|c|c|c|c|c|}
\hline Sources & PDB ID & Resolution (Å) & $\begin{array}{c}\text { Metal Ions } \\
\left(\mathbf{M}_{\mathbf{A}} \mathbf{M}_{\mathbf{B}}\right)\end{array}$ & Inhibitor & Substrate & $\begin{array}{c}\text { Crystal } \\
\text { Assembly }\end{array}$ & References \\
\hline \multirow{18}{*}{$\begin{array}{l}\text { Escherichia } \\
\text { coli }\end{array}$} & $1 \mathrm{AZ9}$ & 2.0 & MnMn & - & - & \multirow{3}{*}{ Tetramer } & \multirow{3}{*}{ [15] } \\
\hline & $1 \mathrm{~A} 16$ & 2.3 & MnMn & ProLeu & - & & \\
\hline & $\begin{array}{c}\text { IJAW } \\
\text { (low pH) }\end{array}$ & 2.7 & MnMn & - & - & & \\
\hline & 1N51 & 2.3 & MnMn & Apstatin & - & Tetramer & [51] \\
\hline & 1WL9 & 1.9 & MnMn & - & - & \multirow{13}{*}{ Tetramer } & \multirow{13}{*}[30]{} \\
\hline & 1WLR & 2.1 & - & - & - & & \\
\hline & 1WL6 & 2.0 & $\mathrm{MgMg}$ & - & - & & \\
\hline & $1 \mathrm{~W} 2 \mathrm{M}$ & 2.4 & Ca- & - & - & & \\
\hline & $2 \mathrm{BHC}$ & 2.4 & Na- & - & - & & \\
\hline & 2BHA & 2.4 & - & - & ValProLeu & & \\
\hline & 2BHD & 2.5 & $\mathrm{MgMg}$ & - & ProLeu $^{1}$ & & \\
\hline & 2BHB & 2.4 & $\mathrm{ZnZn}$ & - & - & & \\
\hline & $\begin{array}{l}\text { No crystal } \\
\text { structure }\end{array}$ & 2.8 & $\mathrm{ZnZn}, \mathrm{Zn}^{2}$ & - & ProLeu $^{1}$ & & \\
\hline & 2BH3 & 2.4 & $\mathrm{ZnZn}, \mathrm{Zn}^{2}$ & ProLeu & - & & \\
\hline & 2BN7 & 2.4 & $\mathrm{MnMn}, \mathrm{Zn}{ }^{2}$ & ProLeu & - & & \\
\hline & 1WBQ & 2.3 & $\mathrm{ZnMg}$ & - & - & & \\
\hline & $1 \mathrm{~W} 7 \mathrm{~V}$ & 2.0 & $\mathrm{ZnMg}$ & - & ProLeu $^{1}$ & & \\
\hline & $5 \mathrm{CNX}$ & 2.6 & \multirow[b]{2}{*}{$\mathrm{ZnZn}$} & - & - & \multirow[b]{2}{*}{ Dimer } & \multirow[b]{2}{*}{ [19] } \\
\hline $\begin{array}{l}\text { Deinococcus } \\
\text { radiodurans }\end{array}$ & $5 \mathrm{G} 1 \mathrm{Q}$ & 1.8 & & - & - & & \\
\hline $\begin{array}{c}\text { Pseudomonas } \\
\text { aeruginosa }\end{array}$ & $5 \mathrm{WZE}$ & 2.0 & MnMn & - & - & Tetramer & [18] \\
\hline
\end{tabular}

${ }^{1}$ The crystal was soaked with the substrate ValProLeu; however, only product ProLeu was observed at the active site. ${ }^{2}$ Zinc ions supplied in excess thereby revealing the third metal-binding site.

EcAPPro (50 kDa) was the first member of the M24B family for which the 3D crystal structure was reported in its native form, in complex with inhibitor and also in low $\mathrm{pH}$ (PDB ID: 1AZ9, 1A16, and 1JAW, respectively) [15]. The native crystal structure (1AZ9) was later refined against the same diffraction data and replaced in the PDB website with a new ID: 1WL9. The latest refinement has rectified some uneven bond lengths and angles at the 
active site of the prior model [30]. The enzymes crystallized as a tetramer or, more precisely, a dimer of dimers and with the monomers folded into two domains. The active site, which is located in the C-terminal domain, comprises a dinuclear manganese center that act as a bridge between the water or hydroxide molecules ready to perform a nucleophilic attack on the scissile peptide bond of Xaa-Pro. Each of the $\mathrm{Mn}^{2+}$ ions are in a distorted octahedral condition. $\mathrm{Mn}_{\mathrm{A}}$ is coordinated by the side chains of Asp271, Glu383, His354, and Glu406 with two water molecules. Meanwhile, $\mathrm{Mn}_{\mathrm{B}}$ is coordinated by Asp260, Asp271, and Glu406 with two water molecules. The crystal structure in low $\mathrm{pH}$ showed that the hydroxide ion that connects the two $\mathrm{Mn}^{2+}$ ions is substituted by one oxygen atom of an acetate ion, while the other oxygen atom of the acetate ion creates a hydrogen bond or salt bridge with the atom of $\mathrm{N}^{\varepsilon 2}$ (His361).

The structure of the Pro-Leu complex reveals that the proline residue of the dipeptide is directly above the bridging hydroxide ion [15]. The dipeptide is known as the competitive inhibitor for APPro and also represents the product that would be produced by the hydrolysis of the tripeptide Xaa-Pro-Leu. Another inhibitor for APPro is apstatin. This inhibitor was designed by incorporating the required proline-specificity on the chemical framework of bestatin and amastatin. Apstatin binds to APPro at the lower part of the active site, where it coordinates the metal ion $\mathrm{Mn}_{\mathrm{B}}$ and, therefore, displaces the coordination water molecule that exists in the native structure [51]. Similar changes also occur to His 243 when the inhibitor Pro-Leu is bound. The imidazole ring of the His243 residue is disorientated within the structure of the native enzyme, as is shown by the absence of 'omit' electron density [15]. Only minor changes are observed in the structure of EcAPPro when the apstatin binds and the polypeptide backbone remain undisturbed. Likewise, the quaternary structure of the enzyme remains unperturbed when both inhibitors, Pro-Leu and apstatin are bound to it [51]. The inhibitor complex also reveals that the side-chain of the N-terminal residue of a substrate fits into a flexible loose pocket that can hold a variety of residues.

Some metalloaminopeptidases require a single metal ion while others require two metal ions for catalysis. Two divalent $\mathrm{Mn}^{2+}$ ions are crucial for the maximal catalytic activity of APPro $[17,20,24,36,44]$. However, the replacement of native $\mathrm{Mn}^{2+}$ with $\mathrm{Co}^{2+}, \mathrm{Zn}^{2+}, \mathrm{Ca}^{2+}$, or $\mathrm{Mg}^{2+}$ results in an enzyme where only $\mathrm{Co}^{2+}-\mathrm{APPro}$ remains catalytically competent when Gly-Pro is used as the substrate [52]. The known metal ligands for these enzymes are His, Glu, Asp, or Lys residues. Besides these metal ligands, at least one additional residue-either Glu, Lys, or Arg-is required for enzymatic catalysis [8]. Measurement of its activity in the presence of $\mathrm{Mn}^{2+}, \mathrm{Mg}^{2+}, \mathrm{Zn}^{2+}, \mathrm{Na}^{2+}$, and $\mathrm{Ca}^{2+}$ demonstrated that only Mn-bound APPro had significant activity and the addition of $\mathrm{Zn}^{2+}$ inhibited the activity of the enzyme. The structure of apo APPro complexed with ValProLeu, a tripeptide substrate, suggests that carboxylate side chains that usually bind the second metal atom can bind the N-terminal amino group of a substrate at the active site, offering a model for substrate binding in a single-metal active enzyme. The structure of an inhibitor complex of Mn-bound APPro and Zn-bound APPro with Pro-Leu revealed a third metal binding site formed by two conserved His residues and the inhibitor in the presence of excess $\mathrm{Zn}$. The binding of a $\mathrm{Zn}$ atom at such a location would thus stabilize product binding and enhance inhibition [30].

APPro from Pseudomonas aeruginosa (PaAPPro) adopts a pita-bread fold configuration and assembles as a tetramer in crystal structures, as shown in Figure 1A. A crystallization experiment on $\mathrm{PaAPPro}$ showed the binding site of $\mathrm{Mn}^{2+}$ ions in the enzyme active site (PDB ID: 5WZE). Figure 1B is a close-up view of the metal atoms in the structure. There are three Mn atoms in each monomer (as shown in Figure 1B). $\mathrm{Mn}_{\mathrm{A}}$ interacts with His354, Asp271, Glu384, and Glu 408 while $\mathrm{Mn}_{\mathrm{B}}$ is liganded by the side chains of Asp260, Asp271, and Glu408. These metal interactions are highly conserved among the APPro structures that appear in the distorted trigonal-pyramidal coordination networks. Metal binding site $\mathrm{B}$ had a relatively weaker binding affinity compared with site $\mathrm{A}$, and this was confirmed through the presence of anomalous signals and 0.5 occupancies of the $\mathrm{Mn}_{\mathrm{B}}$ site of the 
structure feature in metal-dependent aminopeptidase [53]. In addition, the third Mn atom $\left(\mathrm{Mn}_{\mathrm{C}}\right)$ was located in a position formerly identified as being occupied by water in the Zn-load APPro of E. coli structures [30]. Most APPros share a common structure of catalytic domain that contains a metal center flanked by S1-S1' pockets. These pockets have been revealed previously through structural studies on APPro from E. coli in complex with the substrate and inhibitors [30,54]. The ability of APPro to bind to larger substrates is notable due to the extension of the substrate binding site beyond the S1-S1' region [42]. Furthermore, a loop extending from the active site also appears to be crucial for specific large-substrate binding. Through structural comparison and assays of bacteria invasion, this nonconserved surface loop has proven its importance in P. aeruginosa virulence [18]. APPro is capable of modifying protein substrates in contrast to prolidase, which can only cleave dipeptides. A molecular surface of the inhibitor-enzyme complex of EcAPPro and apstatin is shown in Figure 1C. Apstatin is bound to the enzyme at the bottom part of the active site.

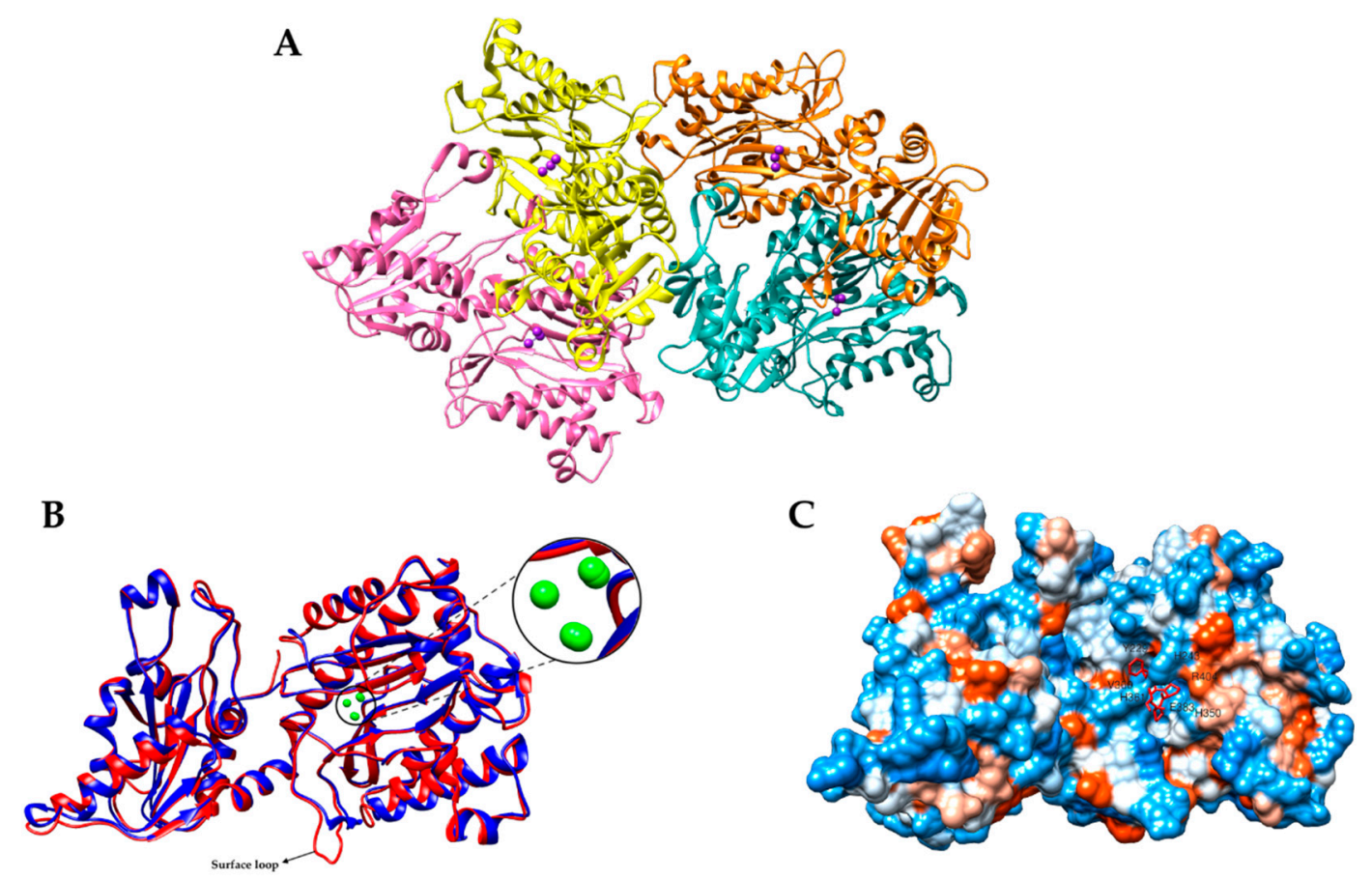

Figure 1. (A) Tetrameric oligomerization of APPro from Psedumonas aeruginosa observed in crystal packing (PDB ID: 5WZE) [18]. $\mathrm{Mn}^{2+}$ metal ions are in purple color. (B) Superposition of 3D secondary structure assignments of the APPro monomers. Blue-E. coli APPro; red-P. aeruginosa APPro. Zoomed image shows the $\mathrm{Mn}^{2+}$ metal ions in green color on both structures. A surface loop was observed in PaAPPro participating in the virulence of P. aeruginosa. (C) Molecular surface of inhibitor-enzyme complex of APPro monomer with apstatin (shown as a red stick model) with labeled specificity pocket (PDB ID: 1N51). All panel images were generated by Chimera [55].

Interestingly, small prokaryotic APPros have been reported from E. coli, L. lactis, D. radiodurans, and $M$. tuberculosis $[19,47,56-58]$. The size of the polypeptide in the small APPro is around $36-39 \mathrm{kDa}$, which is smaller compared with the two-domain APPro $(48-50 \mathrm{kDa})$ and three-domain APPro (70-88 kDa). This type of enzyme is structurally close to small prolidase except for the absence of the dipeptide-selective loop. Through enzymatic characterization, these small enzymes are found indeed to be APPro. A sequence motif DXRY was identified in the N-terminal region of small APPro of E. coli (EcsmAPPro) and its homologs. This could potentially classify small APPro from the closely related M24B peptidases [56]. Mutagenesis of the residues of DXRY of DrsmAPPro revealed that the sequence motif is in fact crucial for enzymatic activity. Crystal structures of EcsmAPPro (PDB ID: 5GIQ) and DrsmAPPro (PDB ID: 5CNX) were solved to $2.6 \AA$ and 
$1.8 \AA$, respectively [19]. Both proteins adopt a two-domain structure typical of the M24B subfamily and form dimers in solution. The $\mathrm{C}$-terminal domain consists of a typical 'pitabread' fold housing the metal binding site. Two $\mathrm{Zn}^{2+}$ metal ions were also revealed in the structure. $Z \mathrm{n}_{\mathrm{A}}$ is penta-coordinated and exhibits distorted trigonal-bipyramidal geometry; $\mathrm{Zn}_{\mathrm{B}}$ is tetracoordinated and shows tetrahedral geometry. Based on their structure, small APPro was almost identical to small type prolidase except for the absence of the loop containing residue of XER motif in small APPro (Figure 2) [19]. This loop has been identified in small prolidase of Xanthomonas campestris, which houses Arg residue that is responsible for dipeptide selectivity. The absence of this loop in the N-terminal domain of small APPro allows this enzyme to hydrolyze longer peptides [50]. Although the structure and metal centers of these enzymes are different, metalloaminopeptidase employ a similar reaction mechanism [8].

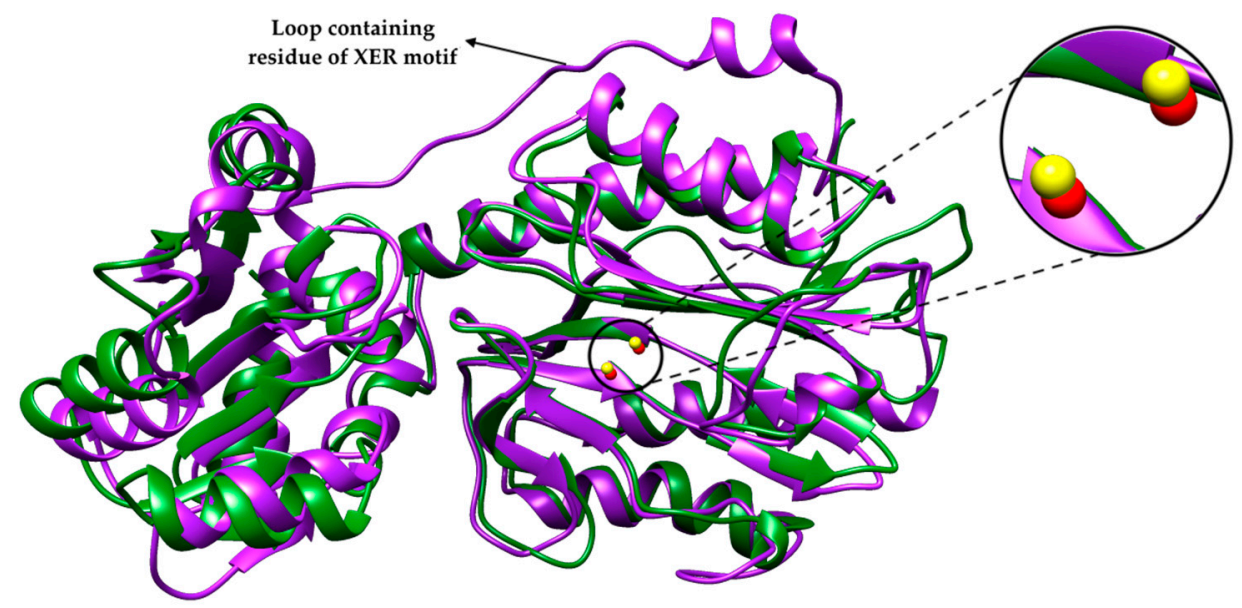

Figure 2. Superposition of 3D structure of small APPro from E. coli (green) and small prolidase from $X$. campestris (purple); PDB ID-5CNX and 5FCF, respectively. The figure was generated by Chimera [55]. Zoom image shows the metal ions on both structures: $\mathrm{Zn}^{2+}$ ions (yellow) for EcsmAPPro and $\mathrm{Mn}^{2+}$ ions (red) for small prolidase.

\subsection{Catalytic Mechanism of APPro}

The catalytic mechanism of APPro from E. coli has been extensively studied [15,30,31,51]. The crystallographic structure of EcAPPro has revealed that the important catalytic residues are His243, His350, His361, Arg404, Tyr387, Asp260, and Trp88 [15]. The specificity of APPro and prolidase is shown by their preference for proline in the $\mathrm{P}^{\prime}$ position. The mechanism of the catalytic activity of APPro involves a nucleophilic attack on a peptide bond and is facilitated by a water molecule that is activated by a divalent metal cation (as shown in Figure 3) [8]. Originally, APPro and MetAP have been identified as requiring two metal atoms for catalysis; however, some can function with only one metal at the active site [41,59-61]. The hydrophobic pocket formed by His350 and Arg404, which correctly orients the substrate for catalysis binds the $\mathrm{P} 1^{\prime}$ proline residue of the substrate. A hydrogen bond formed between $\mathrm{N}^{\varepsilon 2}$ (His243) and the $\mathrm{P} 1^{\prime}$ carbonyl $\mathrm{O}$ atom stabilizes the substrate complex. Meanwhile, the metal ion $\mathrm{Mn}_{\mathrm{B}}$ coordinates the amino group of the P1 substrate residue. The carboxylate side chains of Asp271 and Asp260 are believed to perform the function of $\mathrm{Mn}_{\mathrm{B}}$ in single-metal variants of the enzyme, which is to bind the substrate through salt bridges formed with the same amino group. The carbonyl $\mathrm{O}$ atom of the $\mathrm{P} 1$ residue binds to the metal ion $\left(\mathrm{Mn}_{\mathrm{A}}\right)$ thus polarizing the carbonyl bond by bridging solvent nucleophiles to mediate the nucleophilic attack. A proton is then taken from the nucleophile by Glu383. The gem-diol intermediate formed after the nucleophilic attack is stabilized by His361 and $\mathrm{Mn}_{\mathrm{A}}$. Finally, the donation of the abstracted proton from Glu383 to the $\mathrm{P}^{\prime}$ amine leaving group facilitates the separation of this intermediate into products [31]. 
A

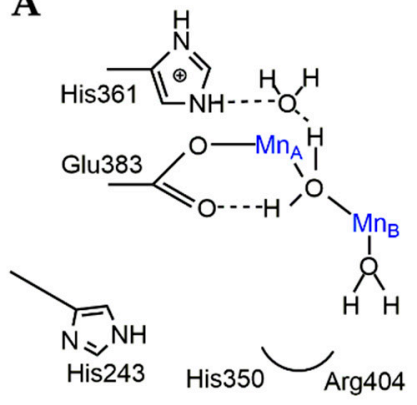<smiles>[Y4]CC1CCCCOC1CCO</smiles>

D

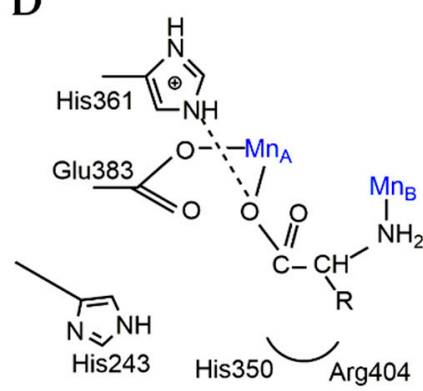

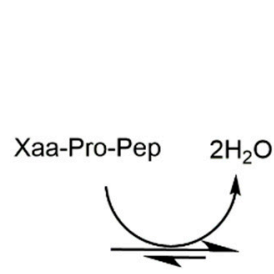

B
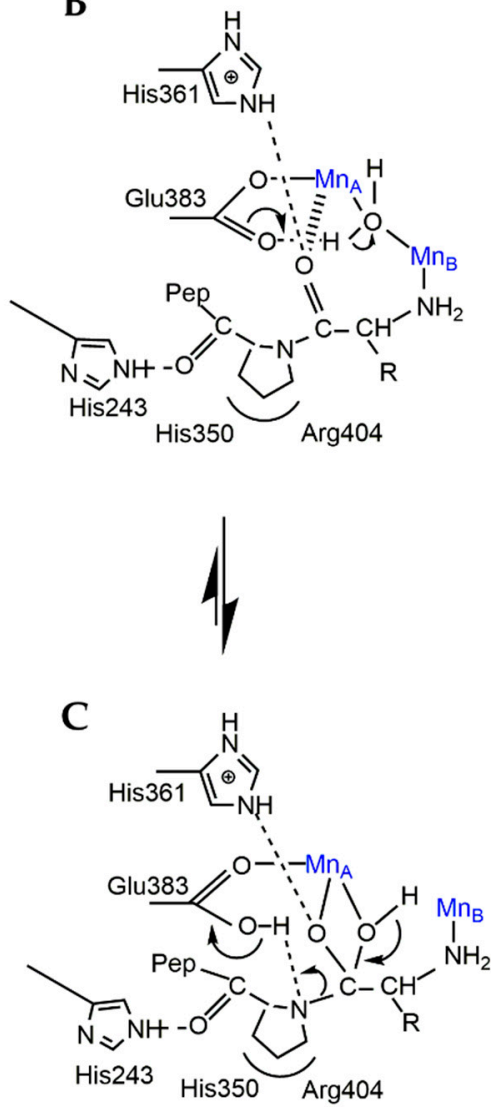

Figure 3. Proposed mechanism of EcAPPro. (A) A water molecule facilitates the nucleophilic attack on a Xaa-Pro peptide bond through the activation of metal ions. (B) His350 and Arg404 forms a hydrophobic pocket which correctly orient the substrate binding. Hydrogen bond between His 243 and the substrate also stabilizes the substrate complex. (C) The gem-diol intermediate is stabilized by His361 and $\mathrm{Mn}_{\mathrm{A}}$ after the nucleophilic attack. (D) The separation of the intermediate into products. The figure was prepared with Chemdraw [62].

A mutational analysis of specific residues was carried out to investigate the roles of conserved residues at the active site of EcAPPro [26,31,54,63]. His243 and His361 play an important role in the catalytic activity of EcAPPro. This has been proven by the substitution of these residues to other amino acids, which decreases the catalytic activity. For example, His243 substituted by alanine leads to a significant decrease in the catalytic performance of EcAPPro. This is due to the His243 stabilizing the substrate binding via its interaction with the carbonyl oxygen of the required proline residue of a substrate. His361 is conserved in the sequences of APPro, prolidase, and MetAP, despite it not being directly implicated in metal binding. Previously, it was identified as being required in the stabilization of substrate binding, and later, it was also proven to be involved in the modulation of the Lewis acidity of the active site metal atoms [31].

Mutation of any of the metal binding residues in EcAPPro, such as Asp260, Asp271, Asp354, and Glu383, to alanine reduces its enzyme activity by at least two orders of magnitude [31]. EcAPPro also has shown its capability of catalyzing the hydrolysis of a wide range of organophosphate (OP) triesters. The substitution of the positively charged Arg153 and Arg370 with hydrophobic side chains leads to the improvement of the hydrolysis rates of the OP substrates. These mutants have been characterized and exhibit a 1.2- to 1.5-fold increased substrate hydrolysis compared with the wild-type enzyme [26]. Substitution of Tyr387 and ARg404 to other residues by site-directed mutagenesis caused a reduction in the $k_{\text {cat }}$ value, indicating that these residues were critical in the hydrolytic mechanism of EcAPPro [63]. A study of APPro from Streptomyces lavendulae conserved residue was 
also carried out by replacing arginine, Arg453 (Arg404 in EcAPPro) with lysine through site-directed mutagenesis [64]. Kinetic analysis of the mutant revealed an increase in $\mathrm{Km}$ with a decrease in Vmax using Gly-Pro-pNA as the substrate, resulting in an overall decrease in catalytic efficiency. This indicates that the guanidinium group of arginine plays a crucial role in substrate binding in APPro [12,64].

The enzymatic activity of APPro has previously been studied using different methods, for example, a modified colorimetric ninhydrin method, [65], various spectrophotometric assays employing other peptidases as auxiliary enzymes (proline iminopeptidase, EC 3.4.11.5; or dipeptidyl peptidase IV, EC 3.4.14.5), using substrates such as GlyPro-pNA or Gly-Pro-Pro-pNa [44,66], colorimetric changes of organophosphate triesters hydrolysis [26,67] and through gas chromatographic assays [57]. Fluorescence-based assays have been used to determine the PepP activity through different synthesized fluorogenic substrates [68-71]. Aminopeptidase P has considerable applications in various fields and sectors due to its substrate-specificity. Apart from the degradation of proline-containing peptides, this enzyme plays an important role, not only in biological pathways, but also in the food industry and in environmental applications [26,27,46].

\section{Industrial Application of Bacterial APPro}

\subsection{Cheese Manufacturing Industry}

Proline-specific peptidases play an important role in the breakdown of casein proteins. The rate of proteolysis determines how quickly a new cheese curd turns into mature cheese. A well-balanced breakdown of milk protein casein into tiny peptides and amino acids is important for developing an acceptable cheese flavor. Casein is high in proline residues and any peptide containing this residue would be resistant to most proteases. Therefore, prolinespecific peptidases play an important role in the breakdown of casein proteins. A few proline-specific aminopeptidases are commonly used in the cheese manufacturing industry, such as proline iminopeptidase, prolyl dipeptidase, and aminopeptidase P [2]. Due to the unique contribution of proline in protein hydrolysate bitterness, an approach using microbial aminopeptidase $P$ has been introduced to improve the taste of cheese. During the cheese fermentation process, peptide degradation occurs from enzymatic digestion of casein.

Aminopeptidase P from lactococcal strains may help in the elimination of bitterness during cheese ripening [27]. Proteolytic enzymes for lactic acid bacteria are very crucial in the formation of flavors during cheese ripening [72]. Aminopeptidases from thermophilic lactic acid bacteria remain active throughout the process of cheese ripening [73]. For example, the ideal time for ripening artisanal Minas cheese, a typical Brazilian cheese, was investigated, and the results revealed that higher temperatures expedited the ripening process due to the presence of a significant amount of aminopeptidases [74]. Thus, the enzyme has proven its industrial potential and application in the food industry, especially in the enzymatic debittering of proline-rich peptide mixtures in food.

\subsection{Enzyme Therapy}

One of the functions of APPro in mammals is its role in the protein turnover of collagen and the regulation of biologically active peptides, including substance $\mathrm{P}$ and bradykinin $[20,40,75]$. Bradykinin, a peptide that promotes inflammation, is released by injured tissues, thereby making an important early contribution to the inflammatory cascade. When given experimentally to human subjects, it produces pain, inflammation, and hyperalgesia [76,77]. It is a physiologically and pharmacologically active peptide of the kinin group of proteins and consists of nine amino acids.

Bradykinin is a potent endothelium-dependent vasodilator and mild diuretic, which helps in lowering blood pressure [78,79]. Apart from being involved in the mechanism of pain, it also causes contraction of nonvascular smooth muscles in the bronchi and gut while increasing vascular permeability. Bradykinin is usually associated with the treatment of hypertension and heart failure. A class of drugs known as the angiotensin converting 
enzyme inhibitors (ACE inhibitors) boost bradykinin levels by preventing its breakdown, thereby increasing its blood pressure lowering effect. These medical drugs are approved by the FDA to treat hypertension and heart failure and are commonly used [79-81]. However, bradykinin is also thought to be the cause of the dry cough found in a few patients who take commonly prescribed ACE inhibitor drugs. It has been found that bradykinin is converted to inactive metabolites by ACE; thereby, inhibiting this enzyme results in an increase in bradykinin levels [82,83]. In some cases, this resultant elevation of bradykinin levels may result in angioedema, which can be a medical crisis and exacerbation of symptoms from hereditary angioedema due to the overactivation of bradykinin $[84,85]$.

Angioedema is a condition where there is an area of swelling of the lower layer of skin and tissue under the skin or mucous membranes. This swelling may occur in the face, tongue, larynx, abdomen, arms or legs, and can be characterized by itchy or painful symptoms [86,87]. In serious cases, the swelling can obstruct the airway of a person resulting in stridor and breathing difficulties, characterized by gasping or wheezing inspiratory breath sounds followed by a decreasing oxygenation level of pulmonary circulation. In humans, bradykinin is processed by three kininases, which are angiotensin-converting enzyme (ACE), aminopeptidase P (APPro), and carboxypeptidase $\mathrm{N}(\mathrm{CPN})$, which cleave the 7-8, $1-2$, and $8-9$ positions, respectively [88,89]. A study carried out in 2002 suggested that low concentrations of aminopeptidase $\mathrm{P}$ could be a predisposing factor for the angioedema development in patients treated with ACE inhibitors.

\subsection{Bioremediation and Decontamination}

Apart from catalyzing the cleavage of amino-terminal Xaa-Pro peptide bonds, aminopeptidase $\mathrm{P}$ was also found to be able to catalyze the hydrolysis of a wide range of organophosphorus triesters $[26,67]$. A proline-specific aminopeptidase $\mathrm{P}$ from $E$. coli has a sequence similarity of $30 \%$ with acid anhydrolase, which is capable of degrading organophosphorus compounds. The catalytic activity of E. coli aminopeptidase P is known to display substrate preference towards methylphosphonate derivatives and organophosphorus compounds [67]. The activity of this enzyme was found enhanced in the presence of metal ions, namely, $\mathrm{Mn}^{+2}$. Hydrolytic activity was carried out using recombinant aminopeptidase $\mathrm{P}$ that underwent mutation against organophosphorus compounds [26].

Organophosphorus compounds or organophosphates (OP) are compounds that have found use as chemical warfare agents (nerve gases), weapons of mass destruction, and as pesticides that have been used to increase agriculture production around the globe, helping to feed the ever-increasing world population. These extremely toxic compounds are inhibitors of acetylcholinesterase (AChE) enzymes, which are involved in nerve impulse transmission in mammals and insects. OP-exposed victims can suffer from brain seizures or convulsions, respiratory failure, and eventually death induced by neuronal death. The lethality of these compounds is demonstrated by the $\mathrm{LD}_{50}$ levels, either by inhalation or intravenous exposure of OPs, either as pesticides or nerve agents. The $\mathrm{LD}_{50}$ levels of OP compounds can be compared to one of the most toxic substances known to man, i.e., botulinum toxin. OP compounds used as pesticides include diazinon, coumaphos, methyl parathion, parathion, fensulfothion, and paraoxon, which have $\mathrm{LD}_{50}$ levels of $80-300 \mathrm{mg} / \mathrm{kg}, 16-41 \mathrm{mg} / \mathrm{kg}, 3-30 \mathrm{mg} / \mathrm{kg}, 2-10 \mathrm{mg} / \mathrm{kg}, 5-10 \mathrm{mg} / \mathrm{kg}$, and 0.5 $\mathrm{mg} / \mathrm{kg}$, respectively. Nerve agent have levels such as DFP $(0.3 \mathrm{mg} / \mathrm{kg})$, sarin, soman, tabun $(0.01 \mathrm{mg} / \mathrm{kg})$, and VX $(0.001 \mathrm{mg} / \mathrm{kg})$, while botulinum toxin has a $\mathrm{LD}_{50}$ level of $0.000001 \mathrm{mg} / \mathrm{kg}[90,91]$. Thus, it can be seen that while OP pesticides are dangerous, when they are developed as nerve agents (chemical weapons), their lethality increases and begin to approach the lethality of botulinum toxin.

In the USA alone, an estimated 40 million $\mathrm{kg}$ of OP compounds have been used on land as pesticides and 20 million $\mathrm{kg}$ are produced for export each year [90]. Globally, OP compounds represent over $38 \%$ of the total pesticides used in agriculture [92]. There are at least 3 million cases of pesticide poisoning, mostly OP-related, and 200,000 deaths worldwide due to either self-poisoning or occupational exposure reported every year by the World 
Health Organization [93,94]. Apart from direct human exposure and residues on food materials, these pesticides are also known to have leached into the ground and into municipal water sources and have polluted many environments surrounding agricultural lands.

Previously, OP compounds were typically disposed of through chemical treatment, open-pit burning, evaporative burial, deep ocean dumping, and also incineration [90]. However, incineration is a costly process and poses yet another environmental problem, which includes the production of toxic emissions and consumption of energy sources. Therefore, other environmentally friendly technologies are now being considered for use in order to replace the use of OPs and to reduce the stockpiles of OPs, including the development of enzymatic detoxification formulations for the degradation of OP compounds both as industrial effluents and environmental pollution [90].

OP-degrading enzymes-for example, $\mathrm{OPH}$-have been successfully incorporated into fire-fighting foam formulations for large-scale response clean-up of contaminated areas [95,96]. Research carried out by LeJeune and Russel in 1999 demonstrated that foam with a height of $1.2 \mathrm{~cm}$ containing $11.4 \mathrm{nM}$ of phosphotriesterase (PTE), a type of OP-degrading enzyme, was able to detoxify a surface contaminated with $1.15 \mathrm{umoL}$ paraoxon $/ \mathrm{cm}^{2}$ with a $43 \%$ conversion rate, and when the height was increased to $3.0 \mathrm{~cm}$, detoxification of the OP was increased by up to a $70 \%$ conversion rate. Similar to OPH, OPAA has also been utilized as an active ingredient in many systems, for example, firefighting foams or sprays, degreasers, laundry detergents, and aircraft deicing solutions and tested for activity after application in these systems $[90,95]$. Under NATO Project Group 31, OPAA enzyme formulations have been tested in conjunction with the development of "Non-Corrosive, Biotechnology-Based Decontaminants for Chemical and Biological Agents" in a variety of forms such as those listed above, and have been found, under certain circumstances, to be capable of achieving more than $99.5 \%$ degradation of the nerve agent soman within 15-30 min [97].

Therefore, aminopeptidase $\mathrm{P}$ could also be further developed using similar methods for integration into foams, sprays, and other liquid-based delivery methods. This will promote an efficient and effective enzyme delivery system due to the help of surface-active agents in the substrate solubilization and adhering of enzyme to vertical surfaces, thus allowing the enzyme to have significant contact time with substrates over a large surface area. This is crucial for the successful decontamination of large areas such as logistic bases, ports, airfields, command and control centers, and other fixed facilities [98].

\section{Conclusions and Future Perspectives}

In conclusion, this review shows that aminopeptidase $\mathrm{P}$ has significant properties that would make this enzyme be capable of cleaving peptides containing proline as a second residue and could therefore play an important role in the regulation of biological activity. The 3D structures of the enzyme display a tetrameric oligomerization in which each subunit adopts a pita bread fold of the C-terminal domain. As a metallopeptidase, this enzyme requires metal ions for its maximal activity. Mutational studies of specific residues were carried out, showing that several residues play an important role in the catalytic activity of the APPro.

Bacterial aminopeptidase $P$ is easily handled and can be overexpressed through various expression systems. However, further improvement in its mass production and catalytic activity needs to be carried out as it is an enzyme that is an exceptional biocatalyst with a wide range of applications across various industries including food and pharmaceutical production.

This potential applicability needs continued research and development of this aminopeptidase with its enhanced properties and characteristics. Various molecular and biochemical approaches, for instance, gene manipulation and protein engineering, can be carried out to improve the specificity of the enzyme, optimal $\mathrm{pH}$, thermostability, and solvent resistance. Beyond that, using computational approaches such as molecular docking and molecular dynamic simulation can also provide a better understanding of the substrate-enzyme 
interactions. Additionally, mutational studies on the structure of the enzyme can also give further insights into its structure and functional properties.

Through the use of molecular technology such as genetic engineering and directed evolution in the screening and processing of suitable microorganisms, the production of aminopeptidase $P$ for industrial and pharmacological applications can be potentially improved. The use of established fermentation techniques using suitably appropriate microorganisms coupled with other bioprocess technologies could facilitate enzyme production. Continuous research in developing these new methods for producing high-quality and cost-effective enzyme production will lead to the broader exploration of applications for aminopeptidase $P$ in various industrial sectors.

\section{Patents}

There are no patents resulting from the work reported in this manuscript.

Author Contributions: M.N.O. and M.S.M.A. researched the literature and wrote the manuscript; R.N.Z.R.A.R., N.D.M.N., W.L. and V.F.K. discussed the idea, and reviewed and edited the manuscript. All authors have read and agreed to the published version of the manuscript.

Funding: This research received no external funding.

Acknowledgments: The authors would like to thank the Graduate Research Fellowship (GRF) from Universiti Putra Malaysia, Malaysia for financial assistance and scholarship.

Conflicts of Interest: The authors declare no conflict of interest.

\section{References}

1. Singh, R.; Kumar, M.; Mittal, A.; Mehta, P.K. Microbial enzymes: Industrial progress in 21st century. 3 Biotech 2016, 6, 174. [CrossRef] [PubMed]

2. Nandan, A.; Nampoothiri, K.M. Therapeutic and biotechnological applications of substrate specific microbial aminopeptidases. Appl. Microbiol. Biotechnol. 2020, 104, 5243-5257. [CrossRef] [PubMed]

3. Taylor, A. Aminopeptidase: Structure and function. FASEB J. 1993, 7, 290-298. [CrossRef] [PubMed]

4. Taylor, A. Aminopeptidases: Towards a mechanism of action. Trends Biochem. Sci. 1993, 18, 167-171.

5. Gonzales, T.; Robert-Baudouy, J. Bacterial aminopeptidases: Properties and functions. FEMS Microbiol. 1996, 18, 319-344. [CrossRef]

6. Kunji, E.R.S.; Mierau, I.; Hagting, A.; Poolman, B.; Konings, W.N. The proteolytic systems of lactic acid bacteria. Antonie Van Leeuwenhoek 1996, 70, 187-221. [CrossRef]

7. Christensen, J.E.; Dudley, E.G.; Pederson, J.A.; Steel, J.L. Peptidases and amino acid catabolism in lactic acid bacteria. Antonie Van Leeuwenhoek 1999, 76, 217-427. [CrossRef]

8. Woessner, J.; Barret, A.; Rawlings, N. Handbook of Proteolytic Enzymes; Elsevier Academic Press: Amsterdam, The Netherlands, 2004

9. Sanz, Y. Aminopeptidases. In Industrial Enzymes; Springer: Dordrecht, The Netherlands, 2007; pp. $243-260$.

10. Rahulan, R.; Manjunath, G.; Nampoothiri, K.M.; Pandey, A. Extracellular Methionine Amino peptidase ( MAP ) Production by Streptomyces gedanensis in Solid-State Fermentation. Braz. Arch. Biol. Technol. 2014, 57, 187-193. [CrossRef]

11. Sanz, Y.; Toldrá, F. Purification and Characterization of an Arginine Aminopeptidase from Lactobacillus sakei. Appl. Environ. Microbiol. 2002, 68, 1980-1987. [CrossRef]

12. Nandan, A.S.; Nampoothiri, K.M. Unveiling aminopeptidase P from Streptomyces lavendulae: Molecular cloning, expression and biochemical characterization. Enzyme Microb. Technol. 2014, 55, 7-13. [CrossRef]

13. Niven, W.G. Purification and characterization of aminopeptidase A from Lactococcus lactis subs.p. lactis NCDO 712 . J. Gen. Microbiol. 1991, 137, 1207-1212. [CrossRef]

14. Nampoothiri, K.M.; Nagy, V.; Kovacs, K.; Szakacs, G.; Pandey, A. L-leucine aminopeptidase production by filamentous Aspergillus fungi. Lett. Appl. Microbiol. 2005, 41, 498-504. [CrossRef]

15. Wilce, M.C.J.; Bond, C.S.; Dixon, N.E.; Freeman, H.C.; Guss, J.M.; Lilley, P.E.; Wilce, J.A. Structure and mechanism of a prolinespecific aminopeptidase from Escherichia coli. Proc. Natl. Acad. Sci. USA 1998, 95, 3472-3477. [CrossRef]

16. Graham, S.C.; Lee, M.; Freeman, H.C.; Guss, J.M. An orthorhombic form of Escherichia coli aminopeptidase P at $2.4 \AA ̊$ resolution. Acta Crystallogr. Sect. D Biol. Crystallogr. 2003, 59, 897-902. [CrossRef] [PubMed]

17. Yaron, A.; Mlynar, D. Aminopeptidase P. Biochem. Phys. Res. Commun. 1968, 32, 658-663. [CrossRef]

18. Peng, C.T.; Liu, L.; Li, C.C.; He, L.H.; Li, T.; Shen, Y.L.; Gao, C.; Wang, N.Y.; Xia, Y.; Zhu, Y.B.; et al. Structure-function relationship of aminopeptidase P from Pseudomonas aeruginosa. Front. Microbiol. 2017, 8, 1-12. [CrossRef] [PubMed] 
19. Are, V.N.; Kumar, A.; Goyal, V.D.; Gotad, S.S.; Ghosh, B.; Gadre, R.; Jamdar, S.N.; Makde, R.D. Structures and activities of widely conserved small prokaryotic aminopeptidases-P clarify classification of M24B peptidases. Proteins Struct. Funct. Bioinforma. 2019, 87, 212-225. [CrossRef]

20. Cunningham, D.F.; O'Connor, B. Proline specific peptidases. Biochim. Biophys. Acta Protein Struct. Mol. Enzymol. 1997, 1343, 160-186. [CrossRef]

21. Phang, J.M.; Liu, W.; Zabirnyk, O. Proline metabolism and microenvironmental stress. Annu. Rev. Nutr. 2010, 30, 441-463. [CrossRef]

22. Wu, G.; Bazer, F.W.; Burghardt, R.C.; Johnson, G.A.; Kim, S.W.; Knabe, D.A.; Li, P.; Li, X.; McKnight, J.R.; Satterfield, M.C.; et al. Proline and hydroxyproline metabolism: Implications for animal and human nutrition. Amino Acids 2011, 40, 1053-1063. [CrossRef]

23. Rawlings, N.D.; Waller, M.; Barrett, A.J.; Bateman, A. MEROPS: The database of proteolytic enzymes, their substrates and inhibitors. Nucleic Acids Res. 2014, 42, 1-7. [CrossRef] [PubMed]

24. Lowther, W.T.; Matthews, B.W. Metalloaminopeptidases: Common functional themes in disparate structural surroundings. Chem. Rev. 2002, 102, 4581-4607. [CrossRef] [PubMed]

25. Feinbaum, R.L.; Urbach, J.M.; Liberati, N.T.; Djonovic, S.; Adonizio, A.; Carvunis, A.R.; Ausubel, F.M. Genome-wide identification of Pseudomonas aeruginosa virulence-related genes using a Caenorhabditis elegans infection model. PLoS Pathog. $2012,8,11$. [CrossRef] [PubMed]

26. Jao, S.C.; Huang, L.F.; Tao, Y.S.; Li, W.S. Hydrolysis of organophosphate triesters by Escherichia coli aminopeptidase P. J. Mol. Catal. B Enzym. 2004, 27, 7-12. [CrossRef]

27. McDonnell, M.; Fitzgerald, R.; Ni Fhaoláin, I.; Jennings, P.V.; O'Cuinn, G. Purification and characterization of aminopeptidase P from Lactococcus lactis subsp. cremoris. J. Dairy Res. 1997, 64, 399-407. [CrossRef] [PubMed]

28. McBroom, A.J.; Johnson, A.P.; Vemulapalli, S.; Kuehn, M.J. Outer membrane vesicle production by Escherichia coli is independent of membrane instability. J. Bacteriol. 2006, 188, 5385-5392. [CrossRef]

29. Vanaja, S.K.; Russo, A.J.; Behl, B.; Banerjee, I.; Yankova, M.; Deshmukh, S.D.; Rathinam, V.A.K. Bacterial Outer Membrane Vesicles Mediate Cytosolic Localization of LPS and Caspase-11 Activation. Cell 2016, 165, 1106-1119. [CrossRef]

30. Graham, S.C.; Bond, C.S.; Freeman, H.C.; Guss, J.M. Structural and functional implications of metal ion selection in aminopeptidase P, a metalloprotease with a dinuclear metal center. Biochemistry 2005, 44, 13820-13836. [CrossRef]

31. Graham, S.C.; Lilley, P.E.; Lee, M.; Schaeffer, P.M.; Kralicek, A.V.; Dixon, N.E.; Guss, J.M. Kinetic and crystallographic analysis of mutant Escherichia coli aminopeptidase P: Insights into substrate recognition and the mechanism of catalysis. Biochemistry 2006, 45, 964-975. [CrossRef]

32. Liu, J.W.; Hadler, K.S.; Schenk, G.; Ollis, D. Using directed evolution to improve the solubility of the C-terminal domain of Escherichia coli aminopeptidase P: Implications for metal binding and protein stability. FEBS J. 2007, 274, 4742-4751. [CrossRef]

33. Jeyakanthan, J.; Takada, K.; Sawano, M.; Ogasahara, K.; Mizutani, H.; Kunishima, N.; Yokoyama, S.; Yutani, K. Crystal Structural and Functional Analysis of the Putative Dipeptidase from Pyrococcus horikoshii OT3. J. Biophys. 2009, 2009, 1-12. [CrossRef] [PubMed]

34. Weaver, J.; Watts, T.; Li, P.; Rye, H.S. Structural basis of substrate selectivity of E. coli prolidase. PLoS ONE 2014,9 , e111531. [CrossRef] [PubMed]

35. Altschul, S.F.; Madden, T.L.; Schäffer, A.A.; Zhang, J.; Zhang, Z.; Miller, W.; Lipman, D.J. Gapped BLAST and PSI-BLAST: A new generation of protein database search programs. Nucleic Acids Res. 1997, 25, 3389-3402. [CrossRef] [PubMed]

36. Bazan, J.F.; Weaver, L.H.; Roderick, S.L.; Huber, R.; Matthews, B.W. Sequence and structure comparison suggest that methionine aminopeptidase, prolidase, aminopeptidase P, and creatinase share a common fold. Proc. Natl. Acad. Sci. USA 1994, 91, 2473-2477. [CrossRef]

37. Hoeffken, H.W.; Knof, S.H.; Bartlett, P.A.; Huber, R.; Moellering, H.; Schumacher, G. Crystal structure determination, refinement and molecular model of creatine amidinohydrolase from Pseudomonas putida. J. Mol. Biol. 1988, 204, 417-433. [CrossRef]

38. Roderick, S.L.; Matthews, B.W. Structure of the Cobalt-Dependent Methionine Aminopeptidase from Escherichia coli: A New Type of Proteolytic Enzyme. Biochemistry 1993, 32, 3907-3912. [CrossRef]

39. Coll, M.; Knof, S.H.; Ohga, Y.; Messerschmidt, A.; Huber, R.; Moellering, H.; Ru, L. Enzymatic mechanism of creatine amidinohydrolase as deduced from crystal structures. J. Mol. Biol. 1990, 214, 597-610. [CrossRef]

40. Yaron, A.; Naider, F.; Scharpe, S. Proline-dependent structural and biological properties of peptides and proteins. Crit. Rev. Biochem. Mol. Biol. 1993, 28, 31-81. [CrossRef]

41. Cottrell, G.S.; Hooper, N.M.; Turner, A.J. Cloning, expression, and characterization of human cytosolic aminopeptidase P: A single manganese(II)-dependent enzyme. Biochemistry 2000, 39, 15121-15128. [CrossRef]

42. Drinkwater, N.; Sivaraman, K.K.; Bamert, R.S.; Rut, W.; Mohamed, K.; Vinh, N.B.; Scammells, P.J.; Drag, M.; McGowan, S. Structure and substrate fingerprint of aminopeptidase P from Plasmodium falciparum. Biochem. J. 2016, 473, 3189-3204. [CrossRef] [PubMed]

43. Arreola, R.; Villalpando, J.L.; Puente-Rivera, J.; Morales-Montor, J.; Rudiño-Piñera, E.; Alvarez-Sánchez, M.E. Trichomonas vaginalis metalloproteinase TvMP50 is a monomeric Aminopeptidase P-like enzyme. Mol. Biotechnol. 2018, 60, 563-575. [CrossRef]

44. Yoshimoto, T.; Murayama, N.; Honda, T.; Tone, H.; Tsuru, D. Cloning and expression of aminopeptidase P gene from Escherichia coli HB101 and characterization of expressed enzyme. J. Biochem. 1988, 104, 93-97. [CrossRef] [PubMed] 
45. Chen, K.C.; Buchanan, T.M. Hydrolases from Neisseria gonorrhoeae. The study of gonocosin, an aminopeptidase-P, a proline iminopeptidase, and an asparaginase. J. Biol. Chem. 1980, 255, 1704-1710. [CrossRef]

46. Lee, H.S.; Kim, Y.J.; Bae, S.S.; Jeon, J.H.; Lim, J.K.; Kang, S.G.; Lee, J.H. Overexpression and characterization of a carboxypeptidase from the hyperthermophilic archaeon Thermococcus sp. NA1. Biosci. Biotechnol. Biochem. 2006, 70, 1140-1147. [CrossRef] [PubMed]

47. Mars, I.; Monnet, V. An aminopeptidase P from Lactococcus lactis with original specificity. BBA Gen. Subj. 1995, 1243, 209-215. [CrossRef]

48. Li, X.; Lou, Z.; Li, X.; Zhou, W.; Ma, M.; Cao, Y.; Geng, Y.; Bartlam, M.; Zhang, X.C.; Rao, Z. Structure of human cytosolic X-prolyl aminopeptidase: A double $\mathrm{Mn}(\mathrm{II})$-dependent dimeric enzyme with a novel three-domain subunit. J. Biol. Chem. 2008, 283, 22858-22866. [CrossRef]

49. Iyer, S.; La-Borde, P.J.; Payne, K.A.P.; Parsons, M.R.; Turner, A.J.; Isaac, R.E.; Acharya, K.R. Crystal structure of X-prolyl aminopeptidase from Caenorhabditis elegans: A cytosolic enzyme with a di-nuclear active site. FEBS Open Bio 2015, 5, $292-302$. [CrossRef]

50. Are, V.N.; Kumar, A.; Kumar, S.; Goyal, V.D.; Ghosh, B.; Bhatnagar, D.; Jamdar, S.N.; Makde, R.D. Crystal structure and biochemical investigations reveal novel mode of substrate selectivity and illuminate substrate inhibition and allostericity in a subfamily of Xaa-Pro dipeptidases. Biochim. Biophys. Acta Proteins Proteom. 2017, 1865, 153-164. [CrossRef]

51. Graham, S.C.; Maher, M.J.; Simmons, W.H.; Freeman, H.C.; Guss, J.M. Structure of Escherichia coli aminopeptidase P in complex with the inhibitor apstatin. Acta Crystallogr. Sect. D Biol. Crystallogr. 2004, 60, 1770-1779. [CrossRef]

52. Zhang, L.; Crossley, M.J.; Dixon, N.E.; Ellis, P.J.; Fisher, M.L.; King, G.F.; Lilley, P.E.; MacLachlan, D.; Pace, R.J.; Freeman, H.C. Spectroscopic identification of a dinuclear metal centre in manganese(II)-activated aminopeptidase P from Escherichia coli: Implications for human prolidase. J. Biol. Inorg. Chem. 1998, 3, 470-483. [CrossRef]

53. Hu, X.V.; Chen, X.; Kee, C.H.; Mildvan, A.S.; Liu, J.O. Kinetic and mutational studies of the number of interacting divalent cations required by bacterial and human methionine aminopeptidases. Biochemistry 2007, 46, 12833-12843. [CrossRef]

54. Graham, S.C.; Guss, J.M. Complexes of mutants of Escherichia coli aminopeptidase P and the tripeptide substrate ValProLeu. Arch. Biochem. Biophys. 2008, 469, 200-208. [CrossRef]

55. Pettersen, E.F.; Goddard, T.D.; Huang, C.C.; Couch, G.S.; Greenblatt, D.M.; Meng, E.C.; Ferrin, T.E. UCSF Chimera - A visualization system for exploratory research and analysis. J. Comput. Chem. 2004, 25, 1605-1612. [CrossRef]

56. Zheng, Y.; Roberts, R.J.; Kasif, S.; Guan, C. Characterization of two new aminopeptidases in Escherichia coli. J. Bacteriol. 2005, 187, 3671-3677. [CrossRef] [PubMed]

57. Stressler, T.; Eisele, T.; Schlayer, M.; Fischer, L. Production, active staining and gas chromatography assay analysis of recombinant aminopeptidase P from Lactococcus lactis ssp. lactis DSM 20481. AMB Express 2012, 2, 1-12. [CrossRef]

58. Simmons, W.H. Aminopeptidase P2. In Handbook of Proteolytic Enzyme; Elsevier: Amsterdam, The Netherlands, 2012; pp. $1528-1532$.

59. Hooper, N.M.; Hryszko, J.; Oppong, S.Y.; Turner, A.J. Inhibition by converting enzyme inhibitors of pig kidney aminopeptidase P. Hypertension 1992, 19, 281-285. [CrossRef]

60. Copik, A.J.; Swierczek, S.I.; Lowther, W.T.; D’Souza, V.M.; Matthews, B.W.; Holz, R.C. Kinetic and spectroscopic characterization of the H178A methionyl aminopeptidase from Escherichia coli. Biochemistry 2003, 42, 6283-6292. [CrossRef] [PubMed]

61. Copik, A.J.; Nocek, B.P.; Swierczek, S.I.; Ruebush, S.; Se, B.J.; Meng, L.; D’Souza, V.M.; Peters, J.W.; Bennett, B.; Holz, R.C. EPR and $\mathrm{X}$-ray crystallographic characterization of the product-bound form of the $\mathrm{Mn}_{\mathrm{II}}$-loaded methionyl aminopeptidase from Pyrococcus furiosus. Biochemistry 2005, 44, 121-129. [CrossRef]

62. Li, Z.; Wan, H.; Shi, Y.; Ouyang, P. Personal experience with four kinds of chemical structure drawing software: Review on chemdraw, chemwindow, ISIS/draw, and chemsketch. J. Chem. Inf. Comput. Sci. 2004, 44, 1886-1890. [CrossRef] [PubMed]

63. Jao, S.C.; Huang, L.F.; Hwang, S.M.; Li, W.S. Tyrosine 387 and arginine 404 are critical in the hydrolytic mechanism of Escherichia coli aminopeptidase P. Biochemistry 2006, 45, 1547-1553. [CrossRef]

64. Nandan, A.; Nampoothiri, K.M. Biochemical and structural analysis of a site directed mutant of manganese dependent aminopeptidase P from Streptomyces lavendulae. J. Biosci. Biotechnol. 2015, 4, 109-116.

65. Doi, E.; Shibata, D.; Matoba, T. Modified colorimetric ninhydrin methods for peptidase assay. Anal. Biochem. 1981, 118, 173-184. [CrossRef]

66. Lasch, J.; Moschner, S.; Sann, H.; Zellmer, S.; Koelsch, R. Aminopeptidase P-a cell-surface antigen of endothelial and lymphoid cells: Catalytic and immuno-histotopical. Biol. Chem. 1998, 379, 705-709. [CrossRef] [PubMed]

67. Hsu, Y.T.; Su, C.Y.; Du, H.C.; Jao, S.C.; Li, W.S. Evaluation of organophosphorus chemicals-degrading enzymes: A comparison of Escherichia coli and human cytosolic aminopeptidase P. Chem. Biodivers. 2008, 5, 1401-1411. [CrossRef] [PubMed]

68. Fleminger, G.; Carmel, A.; Goldenberg, D.; Yaron, A. Fluorogenic Substrates for Bacterial Aminopeptidase P and Its Analogs Detected in Human Serum and Calf Lung. Eur. J. Biochem. 1982, 125, 609-615. [CrossRef] [PubMed]

69. Holtzman, E.J.; Pillay, G.; Rosenthal, T.; Yaron, A. Aminopeptidase P activity in rat organs and human serum. Anal. Biochem. 1987, 162, 476-484. [CrossRef]

70. Hawthorne, S.J.; Harriott, P.; Lim, J.; Turner, A.J.; Walker, B.; Williams, C.H. Evaluation of some fluorogenic substrates for continuous assay of aminopeptidase P. Anal. Biochem. 1997, 253, 13-17. [CrossRef] [PubMed]

71. Stöckel-Maschek, A.; Stiebitz, B.; Koelsch, R.; Neubert, K. A continuous fluorimetric assay for aminopeptidase P detailed analysis of product inhibition. Anal. Biochem. 2003, 322, 60-67. [CrossRef] 
72. Visser, S. Proteolytic Enzymes and Their Relation to Cheese Ripening and Flavor: An Overview. J. Dairy Sci. 1993, 76, 329-350. [CrossRef]

73. Gatti, M.; Fornasari, M.E.; Mucchetti, G.; Addeo, F.; Neviani, E. Presence of peptidase activities in different varieties of cheese. Lett. Appl. Microbiol. 1999, 28, 368-372. [CrossRef]

74. Martins, J.M.; Galinari, É; Pimentel-Filho, N.J.; Ribeiro, J.I.; Furtado, M.M.; Ferreira, C.L.L.F. Determining the minimum ripening time of artisanal Minas cheese, a traditional Brazilian cheese. Braz. J. Microbiol. 2015, 46, 219-230. [CrossRef]

75. Turner, A.J.; Hyde, R.J.; Lim, J.; Hooper, N.M. Structural Studies of Aminopeptidase P. In Cellular Peptidases in Immune Functions and Diseases; Springer: Berlin/Heidelberg, Germany, 1997; pp. 7-16.

76. Meller, S.T.; Gebhart, G.F. A critical review of the afferent pathways and the potential chemical mediators involved in cardiac pain. Neuroscience 1992, 48, 501-524. [CrossRef]

77. Kidd, B.L.; Urban, L.A. Mechanism of inflammatory. Br. J. Anaesth. 2001, 87, 3-11. [CrossRef]

78. Lind, L.; Granstam, S.O.; Millgård, J. Endothelium-dependent vasodilation in hypertension: A review. Blood Press. 2000, 9, 4-15. [CrossRef]

79. Gavras, I. Bradykinin-mediated effects of ACE inhibition. Kidney Int. 1992, 42, 1020-1029. [CrossRef]

80. Ceconi, C.; Francolini, G.; Bastianon, D.; Gitti, G.L.; Comini, L.; Ferrari, R. Differences in the effect of angiotensin-converting enzyme inhibitors on the rate of endothelial cell apoptosis: In vitro and in vivo studies. Cardiovasc. Drugs Ther. 2007, 21, 423-429. [CrossRef] [PubMed]

81. Van Vark, L.C.; Bertrand, M.; Akkerhuis, K.M.; Brugts, J.J.; Fox, K.; Mourad, J.J.; Boersma, E. Angiotensin-converting enzyme inhibitors reduce mortality in hypertension: A meta-analysis of randomized clinical trials of renin-angiotensin-aldosterone system inhibitors involving 158998 patients. Eur. Heart J. 2012, 33, 2088-2097. [CrossRef]

82. Karlberg, B.E. Cough and inhibition of the renin-angiotensin system. J. Hypertens. Suppl. 1993, 11, 3-11.

83. Fox, A.J.; Lalloo, U.G.; Belvisi, M.G.; Bernareggi, M.; Chung, K.F.; Barnes, P.J. Bradykinin-evoked sensitization of airway sensory nerves: A mechanism for ACE-inhibitor cough. Nat. Med. 1996, 2, 814-817. [CrossRef]

84. Bas, M.; Adams, V.; Suvorava, T.; Niehues, T.; Hoffmann, T.K.; Kojda, G. Nonallergic angioedema: Role of bradykinin. Allergy Eur. J. Allergy Clin. Immunol. 2007, 62, 842-856. [CrossRef] [PubMed]

85. Wu, M.A.; Perego, F.; Zanichelli, A.; Cicardi, M. Angioedema Phenotypes: Disease Expression and Classification. Clin. Rev. Allergy Immunol. 2016, 51, 162-169. [CrossRef]

86. Habif, T.P. Clinical Dermatolgy E-Book; Elsevier Health Sciences: Amsterdam, The Netherlands, 2015.

87. Bernstein, J.A.; Cremonesi, P.; Hoffmann, T.K.; Hollingsworth, J. Angioedema in the emergency department: A practical guide to differential diagnosis and management. Int. J. Emerg. Med. 2017, 10, 15. [CrossRef]

88. Kuoppala, A.; Lindstedt, K.A.; Saarinen, J.; Kovanen, P.T.; Kokkonen, J.O. Inactivation of bradykinin by angiotensin-converting enzyme and by carboxypeptidase N in human plasma. Am. J. Physiol. Heart Circ. Physiol. 2000, 278, 1069-1074. [CrossRef] [PubMed]

89. Dendorfer, A.; Wolfrum, S.; Wagemann, M.; Qadri, F.; Dominiak, P. Pathways of bradykinin degradation in blood and plasma of normotensive and hypertensive rats. Am. J. Physiol. Heart Circ. Physiol. 2001, 280, 2182-2188. [CrossRef] [PubMed]

90. Cheng, T.C.; Defrank, J.J. Hydrolysis of Organophosphorus Compounds by Bacterial Prolidases; Springer: Dordrecht, The Netherlands, 2000.

91. Singh, B.K.; Walker, A. Microbial degradation of organophosphorus compounds. FEMS Microbiol. Rev. 2006, 30, 428-471. [CrossRef]

92. Singh, B.K. Organophosphorus-degrading bacteria: Ecology and industrial applications. Nat. Rev. Microbiol. 2009, 7, 156-164. [CrossRef] [PubMed]

93. Bird, S.B.; Sutherland, T.D.; Gresham, C.; Oakeshott, J.; Scott, C.; Eddleston, M. OpdA, a bacterial organophosphorus hydrolase, prevents lethality in rats after poisoning with highly toxic organophosphorus pesticides. Toxicology 2008, 247, 88-92. [CrossRef] [PubMed]

94. Jeyaratnam, J. Acute pesticide poisoning: A major global health problem. World Health Stat Q. 1990, 43, $139-144$.

95. LeJeune, K.E.; Wild, J.R.; Russel, A.J. Nerve agents degraded by enzymatic foams. Nature 1998, 395, 27-28. [CrossRef]

96. Chen, W.; Richins, R.D.; Mulchandani, P.; Kaneva, I.; Mulchandani, A. Biodgradation of organophosphorus nerve agents by surface expressed organophosphorus hydrolase. In Enzymes in Action; Springer: Dordrecht, The Netherlands, $2000 ;$ pp. $211-221$.

97. DeFrank, J.J.; White, W.E. Phosphofluoridates: Biological Activity and Biodegradation. Organofluorines 2006, 3, 295-343. [CrossRef]

98. Theriot, C.M.; Grunden, A.M. Hydrolysis of organophosphorus compounds by microbial enzymes. Appl. Microbiol. Biotechnol. 2011, 89, 35-43. [CrossRef] [PubMed] 